\title{
PENGMASKU
}

Volume 2 No. 1, 2022

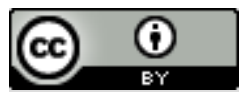

\section{INOVASI PRODUKSI TERHADAP PENINGKATAN USAHA KERIPIK PANGSIT}

\author{
Thea Geby Ayu Santoso ${ }^{1 *}$, Rani Fitriyanti ${ }^{2}$, Nanik Kustiningsih ${ }^{3}$ \\ 1,2,3) theageby@gmail.com, Program Studi Akuntansi STIE Mahardhika Surabaya \\ *penulis korespondensi
}

\begin{abstract}
There are many MSMEs that make businesses in the culinary field in Indonesia, for example, dumpling chips. There are many flavors ranging from spicy lime leaves, $B B Q$, cheese, seaweed, and so on that have been heard and made interesting. To increase product innovation so that the performance of MSMEs increases is the main goal of this MSME. The way to make potential consumers interested is the emergence of innovation from entrepreneurs to understand what effect product innovation has on performance where there is now a lot of competition in the market. This research uses a qualitative case study approach. By using the method of observation can collect the necessary data. The results obtained from data analysis, to improve the performance of MSMEs who want progress, an innovation is made so that the plans designed can be of interest to many people. Improving performance and making plans for innovation is very necessary for the purposes of marketing plans because this way can reduce competition.
\end{abstract}

Keywords : Dumpling chips, Marketing Product Innovation, MSMEs

\begin{abstract}
Abstrak
UMKM yang membuat usaha dalam bidang kuliner di Negara Indonesia sudah sangat banyak, contohnya keripik pangsit. Ada banyak varian rasa mulai dari pedas daun jeruk, BBQ, kerju, rumput laut, dan sebagainya yang telah terdengar serta membuat menarik. Untuk membuat peningkatan inovasi terhadap produk agar kinerja UMKM meningkat adalah tujuan utama dari UMKM ini. Cara membuat calon konsumen tertarik adalah kemunculan inovasi dari pengusaha agar mengerti apa pengaruhnya inovasi produk terhadap kinerja dimana sekarang telah terjadi banyak persaingan di pasar. Penelitian ini menggunakan metode kualitatif pendekatan studi kasus. Dengan menggunakan metode obeservasi dapat mengumpulkan data yang diperlukan. Hasil yang diperoleh dari analisis data, untuk meningkatkan kinerja UMKM yang ingin adanya kemajuan maka dibuatlah suatu inovasi agar rencana yang dirancang dapat diminati banyak orang. Meningkatkan kinerja serta membuat rencana untuk inovasi sangat dibutuhkan untuk keperluan rencana pemasaran karena cara tersebut bisa menurunkan persaingan.
\end{abstract}

Kata Kunci : Inovasi Produk Marketing, Keripik pangsit, UMKM

\section{PENDAHULUAN}

Diseluruh dunia telah dilanda pandemi covid-19, salah satunya Negara Indonesia sangat memberikan perubahan pada ekonomi masyarakat Negara Indonesia dan juga Usaha Mikro Kecil Menengah (UMKM) telah merasakan penurunan pendapatan hingga hampir mengalami kebangkrutan (Sugiarti, Sari, \& Hadiyat, 2020). UMKM harus melakukan cara yang tepat agar usaha yang telah berdiri tidak mengalami kebangkrutan dan bisa bertahan serta membuat UMKM tersebut mengalami peningkatan usaha saat terjadi pandemi.

Menurut Brown dan Petrello (1976), peningkatan usaha adalah usaha tersebut bisa membuat barang ataupun jasa untuk kebutuhan masyarakat. Jika kebutuhan pada masyarakat meningkat maka usaha tersebut juga akan mengalami peningkatan pada usahanya untuk memenuhi kebutuhan masyarakat dan juga usaha terseut bisa memperoleh laba.

Menurut Anoraga (2007:66), peningkatan usaha adalah tanggung jawab yang harus dilakukan oleh usaha tersebut untuk masa kedepannya yang dibutuhkan motivasi serta kreativitas. Jika hal tersebut bisa dilakukan, maka usaha yang awalnya kecil bisa mengalami peningkatan usaha yaitu menjadikan usaha tersebut lebih besar.

Bisa disimpulkan bahwa peningkatan usaha merupakan tanggung jawab yang dimiliki oleh seorang pengusaha yang menghasilkan produk barang ataupun jasa agar bisa memenuhi kebutuhan 


\section{PENGMASKU}

Volume 2 No. 1, 2022

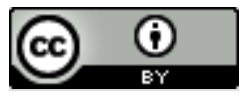

masyarakat dimana pengusaha tersebut memiliki masa depan untuk usahanya, memiliki motivasi dalam berusaha, dan juga kreativitas untuk menjadikan usaha yang mulanya kecil bisa menjadi lebih besar.

Perlu adanya inovasi terhadap produk yang akan dijual oleh seorang pengusaha. Karena tanpa adanya inovasi yang baru, para konsumen tidak menginginkan produk tersebut. Dikarenakan konsumen menyukai produk yang bagus serta harganya juga terjangkau untuk bisa mendapatkan produk yang diinginkan. Inovasi sangat berpengaruh terhadap usaha yang dijalankan dan perlu memiliki ide inovasi yang bagus serta menarik perhatian konsumen sehingga bisa membuat usaha yang dijalankan mengalami peningkatan yang baik.

Inovasi produk berguna untuk menggabungkan berbagai macam proses dimana antara satu dengan yang lainnya bisa berkesinambungan, Kotler (2007:36). Produk dan jasa yang diproduksi oleh usaha baru dipromosikan di pasar. Inovasi terhadap produk dapat disebut dengan produk yang terbaru di dunia, menambahkan inovasi pada produk yang sudah ada, menengahi produk lama dan terbaru, melakukan pengembangan terhadap kesalahan pada produk yang sudah ada, menentukan serta mengurangi biaya, Nasution (2005:44).

Keripik adalah camilan atau makanan ringan yang semua orang tau bahwa rasanya gurih, renyah, dan tidak terlalu mengeyangkan serta terdapat varian rasa yaitu pedas, asin, dan manis. Camilan keripik ini dapat bertahan lama dan praktis di bawa kemana-mana. Jadi bisa disajikan kapanpun dan dimanapun. Seiring berkembangnya zaman, keripik pada jaman sekarang lebih berkembang mulai dari bahan keripik, varian rasa, sampai cara pengemasannya.

Keripik atau camilan berisi bahan baku yang diiris tipis atau kecil-kecil kemudian dicampur dengan adonan tepung dan diberi rempah-rempah agar rasanya menjadi lezat dan gurih. Setelah dicampur adonan tepung dan diberi rempah, kemudian di goreng didalam minyak. Setelah matang, maka camilan bisa di angkat dan siap untuk disantap dengan santai.

Kini keripik atau camilan yang beraneka varian rasa serta bahan baku yang dipakai semakin banyak dikenal oleh kalangan anak muda terutama pada anak-anak, pelajar, dan orang dewasa. Peluang usaha pada keripik atau camilan ini sangat menguntungkan, dikarenakan bahan pembuatannya tidak terlalu mengeluarkan banyak biaya dan juga cara pembuatannya mudah.

Penelitian yang terdahulu berguna untuk mengetahui tentang apa yang telah diletiti pada saat itu, agar tidak terjadi kemiripan dengan penelitian yang baru. Ela Diana, dkk.(2020) yang menjelaskan bahwa tujuan dari adanya melakukan inovasi produk dapat juga membuat peningkatan terhadap kinerja pada perusahaan dan tentunya membuat hal menarik agar customer melirik kepada usaha kita. Dengan cara mensurvei keadaan persaingan pasar sekarang, maka pengusaha akan spontan melakukan kreativitas untuk membuat inovasi produk.

Amalia Arista (2020) yang menjelaskan bahwa di saat berbisnis harus mempunyai pemikiran yang kreatif untuk membuat rencana inovasi yang dapat menarik perhatian konsumen serta mampu mempertahankan produk agar mampu membuat profit menjadi meningkat. Jadi yang diperlukan dalam berbisnis adalah tidak cukup hanya memiliki modal usaha dan juga memiliki kekuatan dalam berbisnis. Untuk mendapatkan keuntungan, maka hal yang dilakukan penguasaha adalah menjadikan dirinya sebagai pengusaha berinovatif yang mampu membuat gagasan serta rencana bagaimana agar bisnis yang dimilikinya bisa berkembang.

\section{METODE}

Dengan cara metode penelitian kualitatif, maka penelitian ini dapat diteliti. Pengertian penelitian kualitatif adalah penelitian yang digunakan untuk mencari, menghasilkan temuan, 


\section{PENGMASKU}

Volume 2 No. 1, 2022

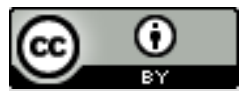

menggambarkan, serta menjelaskan bagaimana mutu atau hal istimewa dari adanya pengaruh social yang tidak bisa dijelaskan, diukur atau digambarkan dengan pendekatan kuantitatif. Saryono (2010)

Penjelasan metode penelitian kualitatif adalah metode penelitian yang berlandaskan oleh filsafat post positivisme, yang digunakan untuk meneliti dengan kondisi obyek yang alamiah,(sebagai lawannya eksperimen) yaitu peneliti berperan sebagai instrumen kunci, mengambil sampel sumber data yang telah didapat dengan melakukan secara purposive dan snowball, tekhnik mengumpulkannya dengan tri-anggulasi atau disebut gabungan, sifat analisis data adalah induktif atau kualitatif serta hasil dari penelitian metode kualitatif lebih mencondongkan arti daripada generalisasi. Sugiyono (2011)

Tujuan dari penelitian metode kualitatif yaitu untuk memahami, mencari makna di balik data, untuk menemukan hasil yang benar, baik benar dalam hal empiris sensual, empiris logis, dan empiris logis. Penelitian yang diteliti adalah inovasi produksi terhadap peningkatan usaha. Tahap pertama adalah observasi inovasi produksi terhadap usaha Cemil Garingan. Peneliti melakukan pengamatan serta mencatat semua permasalahan yang sedang diteliti. Setelah data observasi terkumpul, permasalahan tersebut kemudian di perbaiki. Dan setelah melakukan perbaikan dari permasalahan yang didapat, maka dibuatlah laporan oleh sang peneliti. Laporan harus sesuai dengan permasalahan yang telah di teliti oleh sang peniliti.

\section{HASIL DAN PEMBAHASAN}

Melakukan sebuah usaha tentunya juga memikirkan cara bagaimana agar usaha tersebut bisa mengalami peningkatan dari sebelumnya. Cara tersebut haruslah dibuat dengan baik dan tepat. Peningkatan usaha juga tergantung oleh rencana-rencana kita untuk menarik perhatian para konsumen. Jika rencana kita berhasil maka usaha yang telah berdiri bisa ramai konsumen dan usaha tersebut bisa mendapatkan keuntungan.

Dari rencana yang telah dibuat, "Cemil Garingan" membuat atau mengeluarkan ide untuk menambahkan inovasi rasa, kemasan, harga, dan juga cara pemasaran pada kripik pangsit yang akan dipasarkan. Dengan memperhitungkan modal yang cukup, maka ide tersebut dapat dijalankan sesuai dengan rencana.

Inovasi produk dari usaha "Cemil Garingan" ternyata berpengaruh terhadap peningkatan usaha kripik pangsit. Pengertian produksi merupakan suatu proses kegiatan yang dapat meningkatkan nilai kegunaan terhadap suatu barang atau jasa tersebut. Menemukan produk baru hanya dengan menggunakan biaya efisien yang menyesuaikan kebutuhan dan juga dijual kembali tetapi menggunakan harga yang sesuai dengan kemampuan membeli para consume adalah tujuan umum dari perusahaan yang sedang berkembang. Hal tersebut juga dilakukan oleh Usaha Mikro, Kecil, Menengah (UMKM) Keripik Pangsit "Cemil Garingan", produk keripik pangsit dengan berbagai macam rasa antara lain, Original, Balado, Pedas Daun Jeruk, Keju, Rumput Laut, BBQ.

Dengan 3 macam ukuran small, medium, large. Setiap dihari- hari tertenu mengadakan berbagai macam promo untuk menarik daya beli konsumen. Dalam pendirian usaha ini akan sangat ditentukan oleh kemampuan "Cemil Garingan" untuk memasarkan usaha keripik pangsit. Saat persaingan dalam bisnis yang semakin tinggi seperti sekarang, maka hal yang dilakukan oleh pemilik usaha adalah perlu memikirkan strategi yang tepat untuk mampu menarik pelanggan agar bersedia membeli produk yang teah ditawarkan. Cara tersebut tentunya juga berbeda dengan cara yang telah dipakai sebelumnya.

Berikut adalah perbedaan antara sebelum inovasi dan setelah inovasi : 


\section{PENGMASKU}

Volume 2 No. 1, 2022

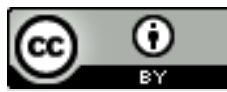

Tabel 1: Menjelaskan Sebelum Inovasi Pada Usaha Keripik Pangsit

\begin{tabular}{|c|c|c|c|}
\hline Kemasan & Rasa & Harga & Pemasaran \\
\hline $\begin{array}{l}\text { Hanya memiliki } \\
\text { satu jenis ukuran }\end{array}$ & $\begin{array}{l}\text { Hanya ada rasa } \\
\text { original }\end{array}$ & $\begin{array}{l}\text { Dipatok dengan } \\
\text { satu harga karena } \\
\text { memiliki satu rasa } \\
\text { dan ukuran }\end{array}$ & $\begin{array}{l}\text { Pemasaran } \\
\text { dilakukan turun } \\
\text { langsung ke } \\
\text { lapangan } \\
\text { dikarenakan belum } \\
\text { adanya pandemi }\end{array}$ \\
\hline $\begin{array}{l}\text { Bahan kemasan } \\
\text { hanya memakai } \\
\text { plastik biasa }\end{array}$ & $\begin{array}{l}\text { Sedikit berminyak } \\
\text { karena kesalahan } \\
\text { saat proses } \\
\text { produksi }\end{array}$ & $\begin{array}{l}\text { Tidak diperjual } \\
\text { sedikit karena } \\
\text { penjual akan } \\
\text { merugi }\end{array}$ & $\begin{array}{l}\text { Jarang adanya } \\
\text { komplain, sehingga } \\
\text { tidak mengetahui } \\
\text { kekurangan dari } \\
\text { produk dan tidak } \\
\text { ada barang } \\
\text { pengganti barang } \\
\text { yang cacat }\end{array}$ \\
\hline $\begin{array}{l}\text { Kemasan yang } \\
\text { digunakan mudah } \\
\text { dimasuki angin } \\
\text { sehingga produk } \\
\text { tidak renyah }\end{array}$ & $\begin{array}{l}\text { Ada cacat } \\
\text { rasa(gosong) terlalu } \\
\text { lama saat di goreng }\end{array}$ & & $\begin{array}{l}\text { Pengantaran barang } \\
\text { berkontak lansgung } \\
\text { antara penjual dan } \\
\text { pembeli. }\end{array}$ \\
\hline
\end{tabular}

Kemasan tidak

memiliki nilai

estetika paada

produk

Tabel 2: Menjelaskan Setelah Inovasi Pada Usaha Keripik Pangsit

\begin{tabular}{llll}
\hline \multicolumn{1}{c}{ Kemasan } & \multicolumn{1}{c}{ Rasa } & \multicolumn{1}{c}{ Harga } & \multicolumn{1}{c}{ Pemasaran } \\
\hline Memiliki 3 jenis & Mempunyai 6 rasa & Tersedia berbagai & Pemasaran hanya \\
ukuran yaitu kecil, & yaitu original, & harga dikarenakan & dilakukan secara \\
sedang, dan besar & BBQ, rumput laut, & memiliki ukuran & online, dikarenakan \\
& $\begin{array}{l}\text { balado, kerju, dan } \\
\text { pedas daun jeruk }\end{array}$ & kemasan yang & keadaan masih \\
& & & $\begin{array}{l}\text { dalam masa } \\
\text { pandemi }\end{array}$ \\
\hline
\end{tabular}




Bahan yang
digunakan
menggunakan
bahan dasar plastic
yang tebal yaitu
standing pouch

Tidak berminyak karena saat melakukan produksi sudah dilakukan penyerapan minyak setelah digoreng
Tidak perlu khawatir meskipun pembelian sedikit ataupun banyak, karena tersedia berbagi ukuran
Sering adanya complain di awal penjualan produk, sehingga penjual bisa mengetahui kekurangan produks dan ada juga mengganti barang yang baru apabila produk yg diterima cacat

Pengantaran barang tidak berkontak langsung antara penjual dan pembeli karena penjual telah menggunakan jasa antar barang

\begin{tabular}{lll}
$\begin{array}{l}\text { Kemasan yang } \\
\text { digunakan tidak }\end{array}$ & $\begin{array}{l}\text { Disaat } \\
\text { penggorengan }\end{array}$ & $\begin{array}{l}\text { Pengantaran barang } \\
\text { tidak berkontak }\end{array}$ \\
\hline mudah dimasuki & diketahui ada & langsung antara \\
angin karena & keripik yang & penjul dan \\
memili perekat & gosong, maka & penjual telah \\
untuk bisa ditutup & keripik gosong & menggunakan jasa \\
kembali & tersebut & antar barang \\
& diminggirkan dan & \\
& tidak dimasukan & \\
& dalam kemasan &
\end{tabular}

\section{Kemasan}

mempunyai nilai

estetik yang bagus

untuk produk

Dari perbedaan diatas terlihat jelas bahwa "Cemil Garingan" mengeluarkan inovasi yang berbeda dari sebelumnya. Karena dalam persaingan bisnis haruslah pintar dalam menarik perhatian konsumen agar usaha yang telah berdiri tidak dipandang bahwa usaha "Cemil Garingan" sama saja dengan usaha yang telah ada. "Cemil Garingan" lebih mementingkan kenyamanan konsumen saat membeli produk keripik pangsit ini. Kenyamanan yang didapat dari konsumen berdampak besar pada usaha karena konsumen bisa menilai baik atau buruknya usaha tersebut.

Di dalam penjualan produk keripik pangsit tidak begitu sulit dalam hal mengatur strategi untuk penjualannya, karena Cemil Garingan telah berinovasi dengan menambahkan banyak varian rasa yang menarik konsumen terlebih memiliki varian rasa yang best seller yaitu Pedas Daun Jeruk. Dalam bisnis kuliner pasti terdapat persaingan, sehingga dalam menghadapi persaingan tersebut, "Cemil Garingan" selalu memberikan pelayanan sebaik mungkin, memberikan kualitas produk serta harga yang terbaik bagi konsumen. Didalam rencana strategi pemasaran, yaitu: produk (product), harga (price), dan promosi (promotion). Strategi dalam bidang pemasaran yang dilakukan cemil garingan dapat dilihat mulai dari produk, harga, tempat atau distribusi, dan promosi adalah sebagai berikut:

1. Produk Usaha yang berhadpan dengan persaingan yang ada di pasar, Cemil Garingan menyediakan keripik pangsit dengan berbagai macam rasa dan ukuran yang banyak diminati 


\section{PENGMASKU}

Volume 2 No. 1, 2022

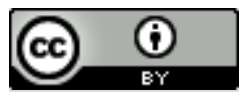

kebanyakan konsumen. Dalam hal pelayanan terhadap komplain yang diberikan oleh pelanggan karena adanya kecacatan produk, maka untuk mengatasi hal tersebut pemilik toko segera memperbaiki bahkan juga mengganti dengan produk baru yang sama. Hal tersebut dilakukan dengan tujuan agar pelanggan tidak kecewa dengan pelayanan dan juga produknya.

2. Harga Strategi penetapan harga oleh pemilik usaha untuk tiap produk Keripik Pangsit :

a. Untuk produk keripik pangsit ukuran small (semua rasa) Rp. 6.000

b. Untuk produk keripik pangsit ukuran medium (semua rasa) Rp. 10.000

c. Untuk produk keripik pangsit ukuran large ( semua rasa) Rp. 15.000

3. Pemasaran UMKM keripik pangsit ini dilakukan secara online dengan menggunakan media market place seperti whatsapp, facebook, instagram, dan juga shopee. Untuk promosi "Cemil Garingan" selalu mengadakan promosi disetiap bulannya. Sebagian besar promosi dilakukan dengan menggunakan word of mouth (cerita dari orang keorang). "Cemil Garingan" juga memberikan potongan harga kepada para konsumen yang berminat bergabung untuk menjadi reseller dengan ketentuan pengambilan 20 bungkus dengan potongan harga Rp.1.500 per bungkus untuk semua produk.

\section{PENUTUP}

\section{Kesimpulan}

Hasil dari penelitian menunjukkan bahwa peningkatan usaha merupakan tanggung jawab yang dimiliki oleh seorang pengusaha yang menghasilkan produk barang ataupun jasa agar bisa memenuhi kebutuhan masyarakat dimana pengusaha tersebut memiliki masa depan untuk usahanya, memiliki motivasi dalam berusaha, dan juga kreativitas untuk menjadikan usaha yang mulanya kecil bisa menjadi lebih besar. Perlu adanya inovasi terhadap produk yang akan dijual oleh seorang pengusaha. Karena tanpa adanya inovasi yang baru, para konsumen tidak menginginkan produk tersebut. Dikarenakan konsumen menyukai produk yang bagus serta harganya juga terjangkau untuk bisa mendapatkan produk yang diinginkan. Rencana-rencana yang telah dibuat harus sudah matang saat usaha mulai berjalan, karena jika rencana telah berjalan dengan baik dan benar, maka usaha tersebut akan menuai hasil yang baik pula.

UMKM pembuat produk juga harus memperbaiki atas kesalahan, meningkatkan kembali dan mengembangkan produk tersebut yang telah diproduksi selama ini, berinovasi terhadap produk usaha sangatlah berpengaruh terhadap UMKM yang dijalankan. Terdapat banyak manfaat dan dampak positif yang akan dirasakan jika bisa berinovasi dengan produk yang diproduksi. Karena dengan berinovsai akan menambah niali guna terhadap produk tersebut.

Tahap pertama adalah observasi inovasi produksi terhadap usaha Cemil Garingan. Peneliti melakukan pengamatan serta mencatat semua permasalahan yang sedang diteliti. Setelah data observasi terkumpul, permasalahan tersebut kemudian di perbaiki. Dan setelah melakukan perbaikan dari permasalahan yang didapat, maka dibuatlah laporan oleh sang peneliti. Laporan harus sesuai dengan permasalahan yang telah di teliti oleh sang peneliti agar penelitian tersebut dapat dipertanggung jawabkan.

Inovasi didalam suatu produk ini bisa terjdi karena terdapat beberapa hal, yaitu diantaranya adalah terdapat feedback dari pelanggan, gabungan dengan hal yang sebelumnya telah ada, hingga terjadi penemuan baru. Produk yang mengalami inovasi akan mendapatkan apresiasi dari para konsumen, sehingga bisa mentarget lebih banyak konsumen serta bisa mendapatkan keuntungan yang berlipat. 


\section{PENGMASKU}

Volume 2 No. 1, 2022

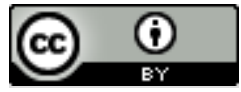

Hal tersebut juga diterapkan oleh UMKM keripik pangsit, yang berinovasi terhadap produknya mulai dari produksi hingga pemasaran agar usaha UMKM tersebut bisa menghasilkan apa yang telah di rencanakan dan mencapai tujuannya. Cara pemasaran pun dengan menggunakan beberapa media online agar konsumen lebih mudah mencari produk yang dipasarkan ini. Dengan cara yang mudah tersebut konsumen tertarik karena pencarian produk yang mudah dan juga harganya terjangkau untuk konsumen.

\section{Saran}

Untuk penelitian berikutnya dalam hal inovasi terhadap peningkatan usaha keripik pangsit perlu dilakukan. Karena didalam membangun sebuah usaha tidak selalu berjalan dengan mulus. Penulis telah meniliti keadaan usaha eripik pangsit yang sekarang sedang berjalan. Maka dari itu penelitian selanjutnya bisa memberikan informasi kembali tentang usaha keripik pangsit yang sekarang sedang berjalan. Penulis hanya ingin menyampaikan, bahwa berinovasi memang sangat penting didalam sebuah usaha. Jadi sebaik mungkin usaha tersebut harus bisa menjaga hubungan antara penjual dan pembeli, agar inovasi yang telah dikeluarkan tidak gagal ditengah jalan.

\section{DAFTAR PUSTAKA}

Anoraga, P. (2007). Pengantar Bisnis: Pendekatan Bisnis dalam Era Globalisasi, Jakarta: Rineka Cipta

Brown \& Pretello https://www.academia.edu/8665059/Ada_beberapa_definisi_pengembangan_usaha_men urut_para_ahli

Kotler, P. (2007). Prinsip-prinsip Pemasaran. Erlangga, Jakarta.

Nasution,M.N. 2005. Total Quality Management. PT.Gramedia Pustaka Utama, Jakarta.

Oktaningrum, dkk,. 2013. Analisis Kelayakan Ekonomis Substitusi Tepung Lokal Pada Pembuatan Keripik Daun Singkong. Balai Pengkajian Teknologi PertanianJawa Tengah.

Raharja, S. U. J., \& Natari, S. U. (2021). Pengembangan usaha umkm di masa pandemi melalui Optimalisasi penggunaan dan pengelolaan media digital, Kumawula: Jurnal Pengabdian Kepada Masyarakat, 4(1), 108-123.

Saputri, E. D., \& Kustiningsih, N. (2020). Pengaruh Inovasi Produk Terhadap Peningkatan Kinerja UMKM Ot Apparel. Journal MISSY (Management and Business Strategy), 1(1), 31-35.

Sriyono. (2012). Skripsi Pembuatan Keripik Umbi Talas (Colocasia giganteum) Dengan Variabel Lama Waktu Penggorengan Menggunakan Alat Vacum Fryer. Universitas Diponegoro. Semarang.

Yuliana, I., Arista, A., \& Kustiningsih, N. (2020). Strategi Inovasi Terhadap Peningkatan Profit Di Masa Pandemi Pada UMKM Our Mask. Journal of Accounting and Financial Issue (JAFIS), 61-66. 